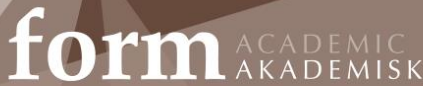

Vol I4, No 2 (202I) https://doi.org/10.7577/formakademisk.4406

Joakim Seiler

PhD

Department of Conservation

University of Gothenburg joakim.seiler@conservation.gu.se

Lars Eriksson

PhD Candidate

Culinary Arts and Meal Science

University of Örebro

lars.g.eriksson@oru.se

Tina Westerlund

PhD, Senior lecturer

Department of Conservation

University of Gothenburg

tina.westerlund@conservation.gu.se

Gunnar Almevik

PhD, Professor

Department of Conservation

University of Gothenburg

gunnar.almevik@conservation.gu.se

\title{
Film article
}

\section{Ways of Tacit Knowing}

\begin{abstract}
A common way to describe craft knowledge is through the figure of speech it's in your hands. With this description, there is no attempt made to explain the complex knowledge which is present in craft. One reason why these explanations are rarely articulated is that they consist of sensory judgments. With this film, Ways of Tacit Knowing, we argue that, with the help of film media, it is possible to decode and articulate some of the knowledge content embodied in craft that is often described as tacit knowledge. We, the producers of this film, are experienced craftspeople, which makes us at once both subjects and objects of the research-a methodology akin to auto-ethnography. In the film, we present examples of situations from practice in our different craft fields: the practice in cultivation and management in gardening and the practice of culinary crafts situated in the kitchen and in the dining room. This film presents a dialogue of knowledge in action with craftspeople who discuss their sensory-based judgments in crafts
\end{abstract}

Keywords:

Craft research, Tacit knowledge, Sensory judgment, Film media, Attention. 


\section{INTRODUCTION}

A common way to describe craft knowledge is through the figure of speech it's in your hands. With this description, there is no attempt made to explain the complex knowledge which is present in craft. One reason why these explanations are rarely articulated is that they consist of sensory judgments. With this film (Figure 1), Ways of Tacit Knowing, we argue that, with the help of film media, it is possible to decode and articulate some of the knowledge content embodied in craft that is often described as tacit knowledge. The research questions investigated in this film are: can tacit knowledge be articulated? And also, the question: how are sensory judgments in craft made and how can we articulate the sensory aspects of craft research and research outputs?

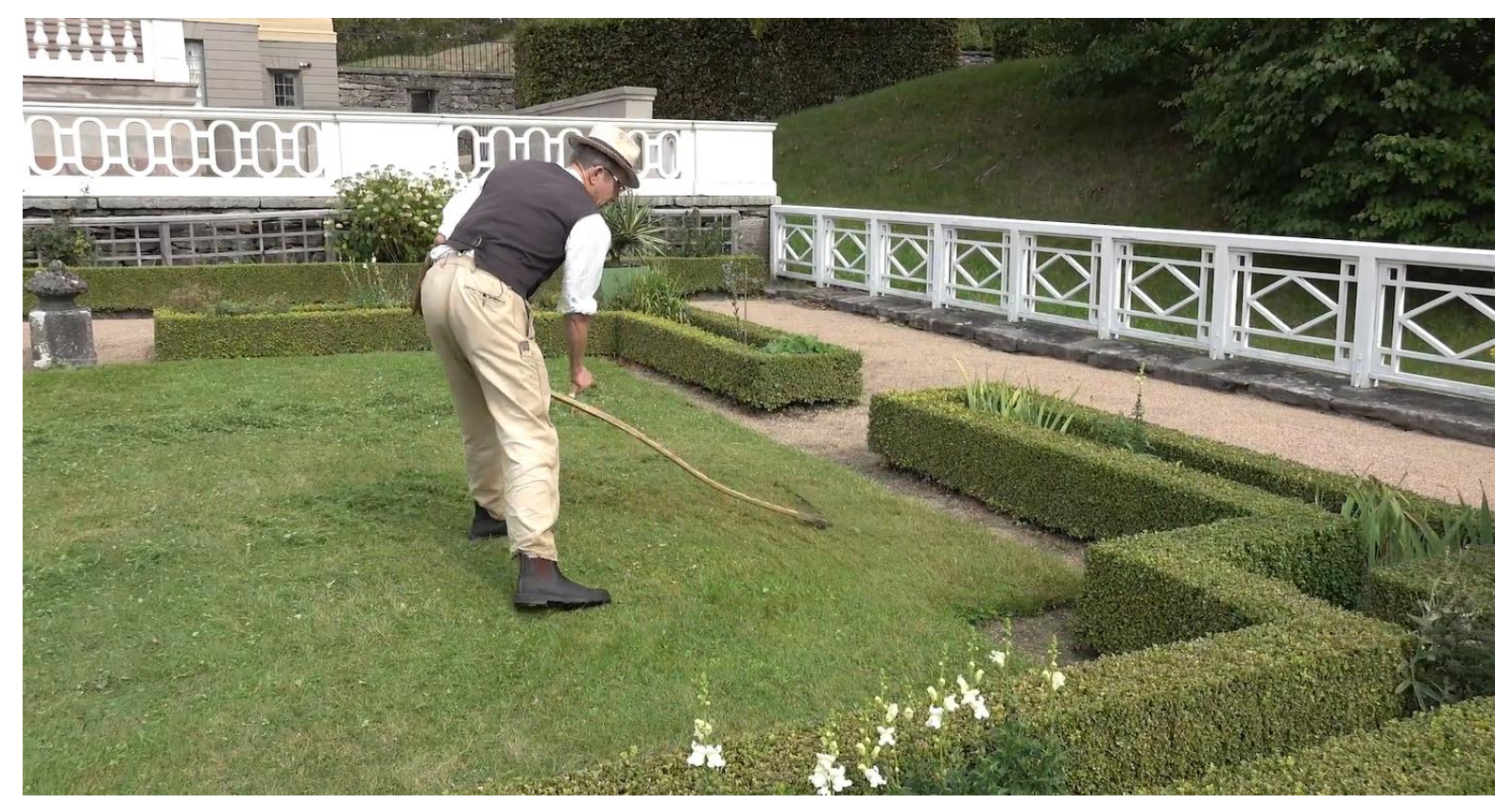

FIGURE 1. The film is about 30 minutes long, and starts with a visit to the sites in Gunnebo House in Mölndal. To watch the video, click the picture

We, the producers of this film, are experienced craftspeople, which makes us at once both subjects and objects of the research-a methodology akin to auto-ethnography. In the film, we present examples of situations from practice in our different craft fields: the practice in cultivation and management in gardening and the practice of culinary crafts situated in the kitchen and in the dining room. This film presents a dialogue of knowledge in action with craftspeople who discuss their sensory-based judgments in crafts.

This film concerns the skills and know-how used in the performance of craft procedures. The implicitness of skills is commonly defined as tacit knowledge, a concept to which Michael Polanyi has contributed. His statement that "we can know more than we can tell" implies a particular way of telling, articulating through text and still images (Polanyi [1966] 2009, p. 64). The film takes on Tim Ingold's argumentation that "we can tell of what we know through practice and experience, precisely because telling is itself a modality of performance that abhors articulation and specification" (Ingold 2013, p. 16). The film explores the questions of how to expand the conception of telling and how to find what Susan Sontag urges us to seek: a relevant descriptive language that attends to the sensuous aspects of craft making (Sontag 1969).

Researchers in fields like ethnography and philosophy point out the need of developing methods that make us more attentive to these sensuous aspects in the study of practice (Pink 2006; Ehn 2011; Molander 2013). By trying film as a method of telling in craft knowledge, we explore its potential to provide a descriptive language of sensory judgments. However, first of all, the sensory 
judgments themselves must be discovered. Our film also shows how film media can be used as a tool to help interested parties pay attention to the type of knowledge that is used in practice. The film was influenced by a desire to investigate a form of media other than text and still images to represent craft knowledge. Craft documentations in film are not a new phenomenon, but the representations are rarely produced by filmmakers who have knowledge in the craft being captured.

We build upon previous research in which film has been used. One example is that of Nicola Wood, a researcher and media designer who is analyzing learning situations between masters and apprentices in wood carving through the use of film (Wood, 2006). The blacksmith and craft researcher Patrik Jarefjäll (2016) has filmed his own performance in the smithy, and craft researcher Camilla Groth (2017) uses verbal accounts documented on video while she is throwing clay in her practice as a ceramist. These researchers use film both to provide a draft base for their own inquiries and to communicate. Their films have no artistic ambitions. Film can be utilized in several ways in craft research and one function is for documentation and data collecting.

The craftsperson can document him/herself when he/she performs his/hers craft in order to be able to study his/her own craft. In this case the films are visual representations of the making. Specific for the auto-ethnographic position of the craft researcher is that he/she not only have the outside perspective of the observer but also of the craft from the 'inside'; the dwelling perspective of Ingold (Ingold, 2000, p. 5). The outside and the inside perspective can be combined in film with the specific method of think aloud accounts. The method builds on verbal accounts and the psychologists Anders K. Ericsson and Herbert Simon studied verbal account as data in their research (1984). Verbal accounts were further developed by education researcher Elisabeth Charters (2003) into think aloud accounts and craft researcher Camilla Groth combined think aloud accounts with video (2017, p. 44). In this present research think aloud accounts are videos in which the craftspersons practice his/her craft and speak about what he/she does in an informal style and telling whatever comes to his/her mind. In this research we use think aloud accounts both as a method of data collection and as an analytical tool.

Film as a research method offers data that can be analyzed and investigated repeatedly. The information is visual, audial and can represent both practice and theory. The data reflect both the visual aspect of craft, how it looks from the observers' perspective, and also with the use of the think aloud method, a record from within the practitioner, how the practice is experienced from the inside.

One possible risk with film as method for data collection and as representation within craft research is the hazard of altering the craft operation when the craft is performed in front of the camera. This risk is present both for new and experienced craftsperson's and can consist in the craftsperson turning to the camera or looking into the camera or adjusting his/her craft practice to the filming situation. This possibly leads to a false representation of how the senses and the body are used in the craft. To tackle this risk, it is important that the both the craftsperson and the person with the camera in the filming situation have some understanding of the craft. In this case the person holding the camera would be more likely to avoid unrealistic craft performances in front of the camera and also be more probable to film the significant details. However, even if this requirement on the camera person is fulfilled, the final film has to be scrutinized with the question: Is this really how we do the craft procedures? In order to overcome the risk of false representation of craft in craft films another option is to record an abundant amount of the craft so that the craftsperson forgets being filmed and does his/her craft as he/she always does. A risk in video documentation is also that craftspersons might want to show their excellence in the craft when the video is made, and thus the documentation fails to show the normal situation. Another, and possibly more demanding, approach is that the craftsperson is a conscious actor and act in the same way as he/she would if the camera hadn't been there. This approach would mean that the craftsperson does not turn towards the camera to get a better view of the craft procedure at the film and also no looking or smiling into the camera.

The methodology consists of experienced craftspeople directing the film to represent the craft knowledge in a realistic way. There is no professional film-maker or expert cameraman. Instead, a key point has been that the person holding the camera has experience of the craft represented in the film. These experiences are code competence for what is essential in the craft procedure and, therefore, what should be highlighted in the film (Sjömar, 2017). No one appearing in the films interferes in the 
line of action, which is important for the scientific value for the audience and for the craftspeople that use the film to understand their own actions.

Film media can be a way to express craft knowledge which is not usually articulated. It releases the craft activity from time and space. The chain of actions can be represented in their complex being, and repeated and studied several times. The craft action can be shown to others and analyzed with other craftpersons. It can also be used as a tool for self-study or self-reflection for the individual craftsperson. What do I do? When do I do it? In this way, the researcher may dig deeper into their field of knowledge. Film media represents the visual, audial, and processual elements of the craft activity to the viewer. Furthermore, it gives a direct demonstration of the human ability of a craftsperson to use all of their senses: taste, smell, hearing, sight, movement, touch, and grasp. Film can make us conscious of the ways we communicate. Still images represent specific dimensions of a craft process, and texts are verbal interpretations or abstractions that reproduce particular dimensions.

These film clips show how craftpersons as reflective practitioners practice their work through their own craft experiences. However, we are convinced that film captures and illuminates more dimensions than other forms of media have been able to. It can show visually the sound, the movement, and the process. Film as media comes close to the craft itself. Through this film, Ways of Tacit Knowing, we argue that we decode and articulate some of the knowledge content embodied in craft that is often described as tacit knowledge.

The film clips showing plant propagation has been made at the Botanical Garden in Gothenburg at the West coast of Sweden. The clips that show culinary craft were made at the School of Hospitality, Culinary Arts \& Meal Science, University of Örebro. Finally, the film clips that show historical gardening and film clips with the researchers' analysis were made at Gunnebo House in Mölndal at the West coast of Sweden. The references in the film are used to support the analysis and verbal argumentation in the film itself, as if the film was a scientific paper, and the purpose is to produce a film that by itself is a scientific product. 


\section{REFERENCES}

Charters, E. (2003). The use of think-aloud methods in qualitative research an introduction to think-aloud methods. Brock Education: A Journal of Educational Research and Practice, 12(2). https://doi.org/10.26522/brocked.v12i2.38

Ehn, B. (2011). Doing-it-yourself: Autoethnography of Manual Work. Ethnologia Europaea, 41(1), 52-63. https://doi.org/10.16995/ee.1077

Ericsson, K. A., \& Simon, H. A. (1984). Protocol analysis: Verbal reports as data. The MIT Press.

Groth, C. (2017). Making Sense through Hands: Design and craft practice analysed as embodied cognition. (Aalto University publication series DOCTORAL DISSERTATIONS, 1/2017)[Doctoral dissertation, Aalto University]. http://urn.fi/URN:ISBN:978-952-60-7130-5

Ingold, T. (2000). The Perception of the Environment: Essays on livelihood, dwelling and skill. Routledge. https://doi.org/10.4324/9780203466025_INTRODUCTION

Ingold, T. (2013). Making: Anthropology, archaeology, art and architecture. Routledge. https://doi.org/10.4324/9780203559055

Jarefjäll, P. (2016). Navarsmide - en metodstudie ur ett hantverksperspektiv. [Licentiatuppsats]. Göteborgs universitet.

Molander, B. (2013). Attentiveness in Musical Practice and Research. Music \& Practice, 1(1). https://doi.org/10.32063/0102

Polanyi, M. (2009). The Tacit Dimension. The University of Chicago Press.

Sontag, S. (1969). Konst och antikonst. PAN/Norstedt.

Sjömar, P. (2017). Hantverksvetenskap - Rapport från försök med hantverksinriktad forskarutbildning. In Almevik, Gunnar (ed.) Hantverksvetenskap. Göteborg: Hantverkslaboratoriet, Göteborgs universitet.

Wood, N. (2006). Transmitting Craft Knowledge: Designing interactive media to support tacit skills learning. [Doctoral dissertation, Sheffield Hallam University]. http://shura.shu.ac.uk/id/eprint/3202 